\title{
Analysis of the ghrelin receptor-independent vascular actions of ulimorelin
}

\author{
John Broad $^{1}$, Brid Callaghan ${ }^{2}$, Gareth J Sanger ${ }^{1}$, James A. Brock ${ }^{2}$ and John B. Furness ${ }^{2}$ \\ ${ }^{1}$ Neurogastroenterology group, Blizard Institute, Barts \& The London School of Medicine and \\ Dentistry, Queen Mary University of London, London, UK, \\ ${ }^{2}$ Department of Anatomy \& Neuroscience, University of Melbourne, Parkville, Victoria 3010, \\ Australia
}

*Proofs and Correspondence to:

Dr John Broad

National Centre for Bowel Research and Surgical Innovation

Blizard Institute

Barts and the London School of Medicine and Dentistry

Queen Mary University of London

$1^{\text {st }}$ Floor Abernethy Building

2 Newark St

London

E1 2AT

Tel. +44 2078826028

Email: j.broad@qmul.ac.uk 


\section{ABSTRACT}

Ulimorelin (TZP101) is a ghrelin receptor agonist that stimulates intestinal motility, but also reduces blood pressure in rodents and humans and dilates blood vessels. It has been proposed as a treatment for intestinal motility disorders. Here we investigated the mechanisms through which ulimorelin affects vascular diameter. Actions of ulimorelin on wall tension of rodent arteries were investigated and compared with other ghrelin receptor agonists.

Saphenous, mesenteric and basilar arteries were obtained from Sprague-Dawley rats (male, 8 weeks) and saphenous arteries were obtained from wild type or ghrelin receptor null mice. These were mounted in myography chambers to record artery wall tension.

Ulimorelin $(0.03-30 \mu \mathrm{M})$ inhibited phenylephrine-induced contractions of rat saphenous $\left(\mathrm{IC}_{50}=0.6 \mu \mathrm{M} ; \mathrm{I}_{\max }=66 \pm 5 \% ; \mathrm{n}=3-6\right)$ and mesenteric arteries $\left(\mathrm{IC}_{50}=5 \mu \mathrm{M}, \mathrm{I}_{\max }=113 \pm 16 \% ; \mathrm{n}=3-4\right)$, but not those contracted by U46619, ET-1 or $60 \mathrm{mM}\left[\mathrm{K}^{+}\right]$. Relaxation of phenylephrine-constricted arteries was not observed with ghrelin receptor agonists TZP102, capromorelin or AZP-531. In rat saphenous and basilar arteries, ulimorelin (10-100 $\mu \mathrm{M})$ and TZP102 (10-100 $\mu \mathrm{M})$ constricted arteries $\left(\mathrm{EC}_{50}=9.9 \mu \mathrm{M} ; \mathrm{E}_{\max }=50 \pm 7 \%\right.$ and $\mathrm{EC}_{50}=8 \mu \mathrm{M} ; \mathrm{E}_{\max }=99 \pm 16 \%$ respectively $)$, an effect not attenuated by the ghrelin receptor antagonist YIL $7813 \mu \mathrm{M}$ or mimicked by capromorelin or AZP531. In mesenteric arteries, ulimorelin, 1-10 $\mu \mathrm{M}$, caused a surmountable rightward shift in the response to phenylephrine $\left(0.01-1000 \mu \mathrm{M} ; \mathrm{A}_{2}=5.7 ; \mathrm{n}=3-4\right)$. Ulimorelin had similar actions in mouse saphenous artery from both wild type and ghrelin receptor null mice.

We conclude that ulimorelin causes vasorelaxation through competitive antagonist action at $\alpha_{1-}$ adrenoceptors and a constrictor action not mediated via the ghrelin receptor.

\section{KEY WORDS}

Ulimorelin, ghrelin, myography, vasodilatation, peripheral arteries

\section{INTRODUCTION}

The peptide hormone, ghrelin, has major roles in the control of appetite, growth hormone release and metabolic functions (Kojima and Kangawa 2005; Kojima and Kangawa 2010; Delhanty and van der Lely 2011). It reduces blood pressure in human and animals when administered intravenously (Nagaya et al. 2001; Okumura et al. 2002) and reduces sympathetic nerve activity when administered into the lower brain stem of rats and rabbits (Matsumura et al. 2002; Lin et al. 
2004). Ghrelin has no direct vasodilatator action on vessels from rat and the ghrelin receptor, growth hormone secretagogue receptor 1a (GHSR1a), is not expressed in rat vessels (Callaghan et al. 2012).

Ulimorelin, also known as TPZ101, is a macrocyclic molecule that is a potent agonist of the ghrelin receptor (Hoveyda et al. 2011). Due to its ability to stimulate gastrointestinal motility, ulimorelin has been evaluated as a possible treatment in gastroparesis (Ejskjaer et al. 2010), ileus (Fraser et al. 2009) and constipation (Pustovit et al. 2014).

We previously showed, in rats, that ulimorelin caused a biphasic reduction in blood pressure with an initial rapid decrease (resistant to ghrelin receptor antagonists), followed by a slower decrease (Callaghan et al. 2014). Ulimorelin also relaxed rat mesenteric arteries preconstricted with phenylephrine, an action not blocked by ghrelin receptor antagonists. Whether ulimorelin relaxes vessels constricted with other agents, or affects arteries in other vascular beds was not investigated, and mechanisms of action were also not investigated. In the current study, we investigated the mechanism(s) by which ulimorelin mediates its effects on vascular constriction, and investigated arteries supplying the viscera, limbs and central nervous system.

\section{MATERIALS AND METHODS}

Male Sprague-Dawley rats, mice with knockout of the gene for the ghrelin receptor, and wildtype C57BL6 mice were used. The knockout was created by inserting a transcriptional blocking cassette into intron 1 of GHSR1a in C57BL6 mice, creating a GHSR1a-null allele (Zigman et al. 2005). All animal procedures were approved by the University of Melbourne Animal Experimentation Ethics Committee. The procedures abided by the Australian Code of Practice for the Care and Use of Animals for Scientific Purposes.

25 adult male Sprague-Dawley rats $(300-400 \mathrm{~g})$ and 8 adult mice $(30-40 \mathrm{~g})$ were killed by increasing atmospheric $\mathrm{CO}_{2}$, followed by exsanguination. The saphenous artery was dissected from its origin at the femoral artery to a point just above the knee joint. Second/third order mesenteric arteries supplying the distal $15 \mathrm{~cm}$ of ileum were isolated from the mesentery. The whole of the basilar artery was isolated. After dissection, all vessels were maintained in physiological saline of the following composition (in $\mathrm{mM}$ ): $\mathrm{Na}^{+}, 150.6 ; \mathrm{K}^{+}, 4.7 ; \mathrm{Ca}^{2+}, 2 ; \mathrm{Mg}^{2+}, 1.2 ; \mathrm{Cl}^{-}, 144.1 ; \mathrm{H}_{2} \mathrm{PO}_{4}{ }^{2-}$, 1.3; $\mathrm{HCO}_{3}{ }^{-}, 16.3$; glucose, 7.8. This solution was gassed with $95 \% \mathrm{O}_{2} / 5 \% \mathrm{CO}_{2}$.

The arteries were cut into $1.2-2 \mathrm{~mm}$ length sections, and mounted isometrically onto stainless steel wires. The rat saphenous arteries were mounted onto $50 \mu \mathrm{m}$ diameter wires, whereas the rat mesenteric, basilar, and mouse saphenous arteries were mounted onto $40 \mu \mathrm{m}$ diameter wires. The basal conditions were normalized by gradually stretching the vessel in small steps until the effective transmural pressure calculated using Laplace's equation [transmural pressure $=$ wall 
tension/(internal circumference $/ 2 \pi$ ), where wall tension $=$ force $/ 2 \times$ vessel segment length] was 13.3 $\mathrm{mN} / \mathrm{mm}^{2}$ (100 mmHg; see Mulvany and Halpern, 1977). The rat and mouse saphenous arteries were suspended at an effective transmural pressure of $100 \mathrm{mmHg}$ (Rummery et al. 2010). The rat mesenteric and basilar arteries were suspended at $90 \%$ of lumen circumference measured at an effective transmural pressure $100 \mathrm{mmHg}$ (see Mulvany and Halpern, 1977). Under these conditions the vessels are mounted at close to the peak of their length-tension relationship. The baths were filled with $6 \mathrm{ml}$ of physiological saline that was continuously bubbled with $95 \% \mathrm{O}_{2} / 5 \% \mathrm{CO}_{2}$ and heated to $36.5 \mathrm{C}$. Following mounting, the arteries were allowed to recover for $30 \mathrm{~min}$.

At the start of all experiments, the tissues were stimulated with three applications of phenylephrine ( 3 or $10 \mu \mathrm{M}$ ) to confirm viability and when the contraction to the third application of phenylephrine had plateaued, carbachol $(1 \mu \mathrm{M})$ was applied to determine if the endothelium was intact. Different tissues were used to assess the effects of each concentration of ghrelin receptor agonist on contractions induced by phenylephrine, methoxamine, U46619, ET-1 and $60 \mathrm{mM}\left[\mathrm{K}^{+}\right]$. The $60 \mathrm{mM}\left[\mathrm{K}^{+}\right]$experiments were performed in the presence of the $\alpha$-adrenoceptor agonists prazosin $100 \mathrm{nM}$ and idazoxan $1 \mu \mathrm{M}$ to prevent the actions of noradrenaline released from the perivascular sympathetic nerve terminals. The test agonists (ghrelin, desacyl ghrelin, ulimorelin, capromorelin, or AZP-351) were applied and left in contact with the tissue for at least 5 min or until the relaxation produced had plateaued. When applied on their own, the concentration of ghrelin receptor agonists was increased cumulatively, with at least $8 \mathrm{~min}$ between each increase in concentration. For cumulative concentration curves to phenylephrine, at least 4 min was allowed to elapse between each addition of phenylephrine. When the effects of receptor antagonists, L-NAME or ion channel blockers were investigated, they were applied at least $30 \mathrm{~min}$ prior to application of ulimorelin.

Data were collected using a Powerlab and Chart 5 software (ADInstruments, Bella Vista, NSW, Australia) and were analysed using GraphPad Prism 5 (GraphPad Software, San Diego, CA). Responses to ghrelin receptor agonists in phenylephrine, methoxamine, endothelin-1, U46619 and $60 \mathrm{mM}\left[\mathrm{K}^{+}\right]$contracted vessels were measured as the $\%$ change in active wall tension from that immediately prior to their addition. Contractions to ghrelin receptor agonists were measured as a $\%$ of the peak force of contraction to phenylephrine ( $3 \mu \mathrm{M}$ for saphenous, $10 \mu \mathrm{M}$ for mesenteric artery) or $60 \mathrm{mM}\left[\mathrm{K}^{+}\right]$(in basilar artery). Both cumulative and non-cumulative curves were fitted using three parameter models. Data are reported as mean \pm S.E.M or, for data generated by the three parameter models, the best-fit parameter determined by nonlinear regression and the standard error is presented; $\mathrm{n}$ is the number of animals. For the Schild plot a linear regression was performed using the $\mathrm{EC}_{50}$ values obtained from the phenylephrine concentration response curves. 1- or 2- way 
ANOVAs, followed by Dunnett's post-tests were used where indicated. $P<0.05$ was considered significant.

The following compounds were used: ulimorelin and TZP102 from Tranzyme Pharma; capromorelin (CP424391) from Pfizer Pharmaceuticals, Sandwich, UK and synthesised by us; carbamylcholine chloride (carbachol), phenylephrine hydrochloride, methoxamine hydrochloride, propranolol hydrochloride, prazocin, idazoxan, atropine, glibenclamide, nifedipine, L-NAME, and ET-1 (from Sigma Aldrich, Sydney, Australia); rat ghrelin (Auspep, Melbourne, Victoria, Australia); rat desacyl ghrelin (GL Biochem, China), AZP-531 (ChinaPeptides, Shanghai, China); YIL 781 and U46619 (Tocris, Bristol, UK). Stock solutions were prepared as follows; ghrelin, desacyl ghrelin, AZP-531 (all 1 mM pH 5.6 acetic acid buffer solution), U46619 (100 $\mu$ M 70\% ethanol), glibenclamide (10 mM in DMSO), nifedipine (1 mM 70\% ethanol), YIL 781 (10 mM 10\% DMSO). All other drugs used were prepared in $\mathrm{dH}_{2} \mathrm{O}$. The carrier solvents, acetic acid buffer, DMSO and ethanol, added alone in the same amounts as in experiments with drugs, had no effects on arterial wall tension in the vessels studied.

\section{RESULTS}

\subsection{Rat saphenous artery}

In rat saphenous artery, ulimorelin $(100 \mathrm{nM}-30 \mu \mathrm{M})$ caused a concentration-dependent inhibition of vasoconstriction elicited by the $\alpha_{1}$-adrenceptor agonist phenylephrine $\left(3 \mu \mathrm{M} ; p \mathrm{IC}_{50}=\right.$ $6.2 \pm 0.2 ; I_{\max }=66 \pm 5 \% ; n=3-6 ;$ Figure 1). This effect was not mimicked by other ghrelin receptor agonists investigated, including ghrelin $(1 \mathrm{nM}-1 \mu \mathrm{M} ; \mathrm{n}=3-4)$, desacyl ghrelin $(1 \mathrm{nM}-$ $1 \mu \mathrm{M} ; \mathrm{n}=3-4)$, TZP102 (10 nM - $30 \mu \mathrm{M} ; \mathrm{n}=3-4)$, capromorelin $(10 \mathrm{nM}-10 \mu \mathrm{M})$, and AZP531 ( $1 \mathrm{nM}-1 \mu \mathrm{M} ; \mathrm{n}=3-4$; Table 1 ) or the vehicles used (data not shown). Table 2 shows that the inhibition of constriction caused by ulimorelin $(1-10 \mu \mathrm{M})$ was not reduced by the ghrelin receptor antagonist YIL $781(3 \mu \mathrm{M}, \mathrm{n}=4)$, the nitric oxide synthase inhibitor L-NAME $(100 \mu \mathrm{M} ; \mathrm{n}$ $=4)$, or the $\beta$-adrenoceptor antagonist propranolol $(1 \mu \mathrm{M} ; \mathrm{n}=4$; table 2$)$. The muscarinic acetylcholine receptor antagonist atropine $(1 \mu \mathrm{M})$ caused a significant attenuation of the response to ulimorelin $(10 \mu \mathrm{M} ; \mathrm{n}=4 ; P<0.01$; Table 2$)$. The L-type calcium channel blocker nifedipine (1 $\mu \mathrm{M} ; \mathrm{n}=4)$ and the $\mathrm{K}_{\mathrm{ATP}}$ channel blocker glibenclamide $(10 \mu \mathrm{M} ; \mathrm{n}=4)$ did not reduce the effects of ulimorelin (Table 2).

Ulimorelin $(1-10 \mu \mathrm{M})$ also inhibited responses to the $\alpha_{1}$-adrenoceptor agonist methoxamine (3 $\mu \mathrm{M})$ by $42 \pm 4 \%(P>0.05)$ but did not inhibit contractions to the thromboxane $\mathrm{A}_{2}$ agonist $\mathrm{U} 46619$ $(100 \mathrm{nM}, \mathrm{n}=4)$ or endothelin $1(\mathrm{ET}-1 ; 100 \mathrm{nM}, \mathrm{n}=3-4$, Table 3). The slow onset of the plateau phase of contraction to ET-1 is likely to be responsible for the apparent increase in artery tension following application of ulimorelin. In addition, ulimorelin did not reduce contractions to $60 \mathrm{mM}$ 
$\left[\mathrm{K}^{+}\right]$(Table 3). Ghrelin $(1 \mu \mathrm{M})$ and desacyl ghrelin $(1 \mu \mathrm{M})$ also had no effect on contractions to ET-1 or U46619 (both $100 \mathrm{nM}$; n = 3; Table 3).

At higher concentrations $(10-100 \mu \mathrm{M})$, ulimorelin on its own caused an increase in artery tension $\left(p \mathrm{EC}_{50}=5.0 \pm 0.2 ; \mathrm{E}_{\max }=50 \pm 7 \% \mathrm{n}=4\right.$; Figure 2$)$, an effect that was attenuated by nifedipine $(1 \mu \mathrm{M} ; P<0.001$ at 30 and $100 \mu \mathrm{M}$ ulimorelin; $\mathrm{n}=3)$. TZP102 $(10-100 \mu \mathrm{M})$ also caused an increase in artery tension (estimated $\left.p \mathrm{EC}_{50}=4.4 ; \mathrm{n}=4\right)$. In contrast, ghrelin $(1 \mathrm{nM}-1$ $\mu \mathrm{M} ; \mathrm{n}=3)$, desacyl ghrelin ( $1 \mathrm{nM}-1 \mu \mathrm{M} ; \mathrm{n}=3)$, capromorelin $(10 \mathrm{nM}-10 \mu \mathrm{M} ; \mathrm{n}=3)$, and AZP531 ( $1 \mathrm{nM}-1 \mu \mathrm{M} ; \mathrm{n}=3$; Table 4), or the vehicles used (data not shown), did not produce this effect (Table 4). The contraction to a single application of a relatively high concentration of ulimorelin ( $30 \mu \mathrm{M} ; 19 \pm 1 \%$ of the contraction to $3 \mu \mathrm{M}$ phenylephrine; $\mathrm{n}=3)$ was not significantly affected by pre-incubation with the $\alpha_{1}$-adrenoceptor antagonist prazosin $(100 \mathrm{nM} ; 46 \pm 12 \% \mathrm{n}=3$; $P>0.05)$ or YIL $781(3 \mu \mathrm{M} ; 29 \pm 9 \% \mathrm{n}=3 ; P>0.05)$.

\subsection{Rat mesenteric and basilar artery}

In the rat mesenteric arteries, ulimorelin $(100 \mathrm{nM}-30 \mu \mathrm{M})$ also caused concentrationdependent relaxation of phenylephrine $(10 \mu \mathrm{M})$-induced contractions $\left(p \mathrm{IC}_{50}=5.3 \pm 0.2, \mathrm{I}_{\max }=113\right.$ $\pm 16 \% ; n=3-4$; Figure 1), but did not cause constriction on its own $(100 \mathrm{nM}-100 \mu \mathrm{M} ; \mathrm{n}=3)$. This allowed the construction of cumulative concentration response curves to phenylephrine in the presence of ulimorelin (100 nM - $10 \mu \mathrm{M} ; \mathrm{n}=3-4$; Figure 3). Ulimorelin caused a surmountable, concentration dependent shift in the concentration response curve to phenylephrine with a $p \mathrm{~A}_{2}$ value of 5.7 (slope of Schild plot $=-0.7 \pm 0.2$; Figure 3 ).

Rat basilar arteries did not respond to phenylephrine $(3 \mu \mathrm{M} ; \mathrm{n}=4)$, as previously reported for noradrenaline (Chang et al. 1988). Ulimorelin (10 $\mu \mathrm{M} ; \mathrm{n}=3)$ caused a small, but consistent inhibition of $60 \mathrm{mM}\left[\mathrm{K}^{+}\right]$stimulated contractions (by $24 \pm 12 \% ; \mathrm{n}=3 ; P>0.05$ ), and on its own increased in basilar artery tension $\left(p \mathrm{EC}_{50}=5.1 \pm 0.3 ; \mathrm{E}_{\max }=99 \pm 16\right.$ of $60 \mathrm{mM}\left[\mathrm{K}^{+}\right]$-induced contraction; $\mathrm{n}=3$; Figure 2).

\subsection{Saphenous artery from wild-type and ghrelin receptor null mice}

In the saphenous artery from mice lacking the ghrelin receptor, and wild type littermates, ulimorelin had similar effects to those observed in rat saphenous artery. Ulimorelin $(1-10 \mu \mathrm{M})$ relaxed phenylephrine $(3 \mu \mathrm{M})$ contracted vessels (by $61 \pm 17 \%$ and $51 \pm 16 \%$ respectively at 10 $\mu \mathrm{M} ; P>0.05 ; \mathrm{n}=3$ ). On its own, ulimorelin increased saphenous artery tension (in wild type $p \mathrm{EC}_{50}=4.7 \pm 0.3 ; \mathrm{E}_{\max }=15 \pm 3 \%$ of contraction to phenylephrine $3 \mu \mathrm{M} ; \mathrm{n}=3$; in mice lacking the 
ghrelin receptor $p \mathrm{EC}_{50}=4.8 \pm 0.4 \mu \mathrm{M} ; \mathrm{E}_{\max }=23 \pm 6 \%$ of contraction to phenylephrine $3 \mu \mathrm{M} ; \mathrm{n}=$ $3 ; P>0.05$; Figure 4).

\section{DISCUSSION}

In a previous study of ulimorelin's effects, a vasodilatator effect on arteries preconstricted with phenylephrine was reported (Callaghan et al. 2014). Ghrelin receptor antagonists, JMV2959 and YIL 781 (Esler et al. 2007), did not inhibit this effect and ghrelin receptor expression was not detected in the arteries. In the current work, we observed that ulimorelin caused vasodilatation in saphenous arteries from rats, as well as wild type and Ghsr null mice, which supports that conclusion that vasodilatation is mediated through a receptor different to the ghrelin receptor. Two classes of ghrelin receptors, other than GHSR1a, have been pharmacologically identified at which ghrelin and compounds related to ghrelin act, the ghrelin receptor-like receptors (GRLRs), where ghrelin and desacyl ghrelin are both active, and the unacylated ghrelin (UAG) receptors at which desacyl ghrelin but not ghrelin is an effective agonist (Callaghan and Furness, 2014). The sites identified in the present study do not match GRLRs or UAG receptors as neither ghrelin nor desacyl ghrelin have a vasodilatator action in the arteries investigated.

The potencies of ulimorelin at mediating the effects described in this study were quite different from those at the ghrelin receptors. At rat and human ghrelin receptors, ulimorelin has an $\mathrm{EC}_{50}$ in the range of 1-2 nM (Hoveyda et al. 2011; Callaghan et al. 2014). For relaxation of preconstricted arteries, the $\mathrm{EC}_{50}$ of ulimorelin was $0.5-5 \mu \mathrm{M}$ and for contraction the $\mathrm{EC}_{50}$ was $10-30 \mu \mathrm{M}$, providing further evidence that these effects are not mediated by the ghrelin receptor. The concentrations of ulimorelin we studied are within the range achieved in vivo following infusion of $160-600 \mu \mathrm{g} / \mathrm{kg}$ ulimorelin which produced peak plasma concentrations in the range $6-14 \mu \mathrm{M}$ (Lasseter et al. 2008). However, the approximately 1000-fold lower potency at the off-target sites identified in the current study suggests that they can be avoided in therapeutic applications of ulimorelin targeting the ghrelin receptor.

The experiments indicate that a major component of the vasodilatation is due to antagonism of $\alpha_{1}$-adrenoceptors. Evidence for $\alpha_{1}$-adrenoceptor antagonism is that vasodilatation was observed in arteries preconstricted with $\alpha_{1}$-adrenoceptor agonists, phenylephrine or methoxamine, but not in vessels preconstricted with endothelin-1 or the thromboxane $A_{2}$ agonist U46619. Moreover, in rat mesenteric artery, ulimorelin shifted the concentration-response curve for phenylephrine to the right with a $p \mathrm{~A}_{2}$ of 5.7. Performing these studies in mice lacking $\alpha_{1}$-adrenoceptors may assist in confirming these conclusions. 
A number of off-target effects for other ghrelin receptor ligands at known non-ghrelin receptors have been identified, including $\beta_{3}$-adrenoceptor agonist activity by (4-[(aminocarbonyl)amino]-N[4-(2-aminoethyl)phenyl]benzenesulfonamides (Pasternak et al. 2009) and muscarinic receptor agonist activity by spiro-azetidine-piperidine analogues (McClure et al. 2013). In our study, propranolol did not reduce the vasodilatator action of ulimorelin, excluding a role for $\beta_{3^{-}}$ adrenoceptors. However, atropine did reduce the vasodilatator action of ulimorelin, suggesting it may in part be mediated via endothelial muscarinic receptors. Previously it has been reported that in rat mesenteric artery endothelial denudation reduced but did not abolish vasodilatation to ulimorelin (Callaghan et al. 2014).

In addition to its vasodilatator effect, relatively high concentrations of ulimorelin caused constriction of rat and mouse saphenous and rat basilar artery. Constriction was observed in saphenous artery segments from Ghsr null mice suggesting this effect was not mediated by the ghrelin receptor. Similar concentrations of TZP102 also caused constriction of rat saphenous artery, but other ghrelin receptor agonists investigated had no constrictor effect in this vessel. This suggests that the macrocyclic molecules, ulimorelin and TZP102, may possess a structurally related molecular motif that is responsible for their contractile effects and that is absent in the other ghrelin receptor agonists investigated. Comprehensive structure-activity relationship investigations will be required to identify the particular motif responsible.

The contractile effects of ulimorelin observed in the rat saphenous and basilar arteries were not observed in rat mesenteric arteries. These observations suggest the expression of a common molecular entity (possibly an ion channel or receptor) mediating the contractile effects of ulimorelin in the saphenous and basilar arteries that is not expressed in the mesenteric arteries. Determining the particular entity mediating this effect is beyond the scope of this investigation.

The basilar artery was contracted using $60 \mathrm{mM}\left[\mathrm{K}^{+}\right]$as there was no contraction to phenylephrine. This absence of $\alpha$-adrenoceptor-mediated contractions in rat basilar arteries has been previously reported (Chang et al. 1988). Only a small vasodilatation of the basilar artery contracted with $60 \mathrm{mM}\left[\mathrm{K}^{+}\right]$was observed following application of ulimorelin, making this vessel an ideal place to investigate the vasoconstriction. The reduced vasodilatation to ulimorelin observed in this artery adds further evidence to support the $\alpha$-adrenoceptor antagonist effect of ulimorelin observed in both the saphenous and mesenteric arteries.

\section{CONCLUSION}

Here, for the first time, the ghrelin receptor agonist ulimorelin has been shown to have two distinct, regionally selective, non-ghrelin receptor mediated actions on arteries in rodents, namely a 
reduction in $\alpha_{1}$-adrenoceptor-mediated constriction and, at a higher concentrations, a vasoconstrictor action. The vasodilatator mechanisms are unknown, however the evidence presented suggests inhibition of $\alpha_{1}$-adrenoceptors, and activation of muscarinic acetylcholine receptors, mediates this action of ulimorelin. The mechanism of constriction is currently unknown although opening of L-type calcium channels appears to be required. As the concentrations of ulimorelin producing these non-ghrelin receptor-mediated effects may be achieved in vivo, this may aid interpretation of studies of the effects of ulimorelin on blood pressure.

\section{ACKNOWLEDGEMENTS}

John Broad was supported by the Outstanding Young Investigator Award of the British Pharmacological Society and the Australasian Society of Clinical and Experimental Pharmacologists and Toxicologists. Research support was provided by the National Health and Medical Research Council of Australia (Project Grant 1005811) and the Transport Accident Commission through the Institute for Safety Compensation and Recovery Research (Grant N-13085).

\section{References:}

Callaghan B, Hunne B, Hirayama H, Sartor DM, Nguyen TV, Abogadie FC, Ferens D, McIntyre P, Ban K, Baell J, Furness JB, Brock JA (2012) Sites of action of ghrelin receptor ligands in cardiovascular control. Am. J. Physiol. 303:H1011-H1021

Callaghan B, Kosari S, Pustovit RV, Sartor DM, Ferens D, Ban K, Baell J, Nguyen TV, Rivera LR, Brock JA, Furness JB (2014) Hypotensive effects of ghrelin receptor agonists mediated through a novel receptor. Br. J. Pharmacol. 171:1275-1286

Callaghan B, Furness JB (2014) Novel and conventional receptors for ghrelin, desacyl-ghrelin and pharmacologically related compounds. Pharmacol. Rev. 66: 984-1001

Chang J-Y, Hardebo JE, Owman CH (1988) Differential vasomotor action of noradrenaline, serotonin, and histamine in isolated basilar artery from rat and guinea-pig. Acta Physiol. Scand. 132:91-102

Delhanty PJD, van der Lely AJ (2011) Ghrelin and glucose homeostasis. Peptides 32:2309-2318 Ejskjaer N, Dimcevski G, Wo J, Hellström PM, Gormsen LC, Sarosiek I, Søfteland E, Nowak T, Pezzullo JC, Shaughnessy L, Kosutic G, McCallum R (2010) Safety and efficacy of ghrelin agonist TZP-101 in relieving symptoms in patients with diabetic gastroparesis: a randomized, placebo-controlled study. Neurogastroenterol. Motil. 22:1069-e1281

Esler WP, Rudolph J, Claus TH, Tang W, Barucci N, Brown SE, Bullock W, Daly M, DeCarr L, Li Y, Milardo L, Molstad D, Zhu J, Gardell SJ, Livingston JN, Sweet LJ (2007) Smallmolecule ghrelin receptor antagonists improve glucose tolerance, suppress appetite, and promote weight loss. Endocrinology, 148 (11): 5175-85

Fraser GL, Venkova K, Hoveyda HR, Thomas H, Greenwood-Van Meerveld B (2009) Effect of the ghrelin receptor agonist TZP-101 on colonic transit in a rat model of postoperative ileus.

Eur. J. Pharmacol. 604:132-137

Hoveyda HR, Marsault E, Gagnon R, et al. (2011) Optimization of the potency and pharmacokinetic properties of a macrocyclic ghrelin receptor agonist (Part I): development of ulimorelin (TZP-101) from hit to clinic. J. Med. Chem. 54:8305-8320

Kojima M, Kangawa K (2005) Ghrelin: Structure and function. Physiol. Rev. 85:495-522 
Kojima M, Kangawa K (2010) Ghrelin: more than endogenous growth hormone secretagogue. Ann. N. Y. Acad. Sci. 1200:140-148

Lin Y, Matsumura K, Fukuhara M, Kagiyama S, Fujii K, Iida M (2004) Ghrelin acts at the nucleus of the solitary tract to decrease arterial pressure in rats. Hypertension 43:977-982

Matsumura K, Tsuchihashi T, Fujii K, Abe I, Iida M (2002) Central ghrelin modulates sympathetic activity in conscious rabbits. Hypertension 40:694-699

McClure KF, Jackson M, Cameron KO, Kung DW, Perry DA, Orr ST, Zhang Y, Kohrt J, Tu M, Gao H, Fernando D, Jones R, Erasga N, Wang G, Polivkova J, Jiao W, Swartz R, Ueno H, Bhattacharya SK, Stock IA, Varma S, Bagdasarian V, Perez S, Kelly-Sullivan D, Wang R, Kong J, Cornelius P, Michael L, Lee E, Janssen A, Steyn SJ, Lapham K, Goosen T (2013) Identification of potent, selective, CNS-targeted inverse agonists of the ghrelin receptor. Bioorg. Med. Chem. Lett. 23:5410-5414

Mulvany MJ, Halpern W (1977). Contractile properties of small arterial resistance vessels in spontaneously hypertensive and normotensive rats. Circ Res 41: 19-26.

Nagaya N, Kojima M, Uematsu M, Yamagishi M, Hosoda H, Oya H, Hayashi Y, Kangawa K (2001) Hemodynamic and hormonal effects of human ghrelin in healthy volunteers. Am. J. Physiol. 280:R1483-R1487

Okumura H, Nagaya N, Enomoto M, Nakagawa E, Oya H, Kangawa K (2002) Vasodilatory effect of ghrelin, an endogenous peptide from the stomach. J. Cardiovasc. Pharmacol. 39:779-783

Pasternak A, Goble SD, deJesus RK, Hreniuk DL, Chung CC, Tota MR, Mazur P, Feighner SD, Howard AD, Mills SG, Yang L (2009) Discovery and optimization of novel 4[(aminocarbonyl)amino]- $N$-[4-(2-aminoethyl) phenyl]benzenesulfonamide ghrelin receptor antagonists. Bioorg. Med. Chem. Lett. Nov 1;19(21):6237-40

Pustovit RV, Callaghan B, Kosari S, Rivera LR, Thomas H, Brock JA, Furness JB (2014) The mechanism of enhanced defecation caused by the ghrelin receptor agonist, ulimorelin. Neurogastroenterol. Motil. 26:264-271

Rummery NM, Tripovic D, McLachlan EM, Brock JA (2010) Sympathetic vasoconstriction is potentiated in arteries caudal but not rostral to a spinal cord transection in rats. $\mathrm{J}$ Neurotrauma. Nov;27(11):2077-89

Zigman JM, Nakano Y, Coppari R, Balthasar N, Marcus JN, Lee CE, Jones JE, Deysher AE, Waxman AR, White RD, Williams TD, Lachey JL, Seeley RJ, Lowell BB, Elmquist JK (2005) Mice lacking ghrelin receptors resist the development of diet-induced obesity. J. Clin. Invest. 115:3564-3572 


\section{FIGURE LEGENDS}

Fig. 1 Ulimorelin causes a decrease in saphenous and mesenteric artery tension following stimulation with phenylephrine. Panels A and B display representative traces of the inhibition of phenylephrine-induced contractions of rat (A) saphenous and (B) mesenteric arteries by ulimorelin. Panels $\mathrm{C}$ and D display non-cumulative concentration response curves showing the inhibition of phenylephrine-induced contractions in (C) saphenous and (D) mesenteric arteries.

Fig. 2 Ulimorelin contracts rat saphenous and basilar arteries. Panels A and B display representative traces of ulimorelin-induced contractions of rat (A) saphenous and (B) basilar arteries. Arrowheads indicate times and concentrations of ulimorelin added. Panels C and D display cumulative concentration contraction curves for ulimorelin in (C) saphenous and (D) basilar arteries.

Fig. 3 Ulimorelin alters the concentration-response relationship for phenylephrine in rat mesenteric arteries. Panel A displays cumulative concentration contraction curves for phenylephrine in the presence of $0,100 \mathrm{nM}, 1 \mu \mathrm{M}$, and $10 \mu \mathrm{M}$ ulimorelin. A surmountable shift in the concentration contraction curve for phenylephrine was observed in the presence of $10 \mu \mathrm{M}$ ulimorelin. Panel B shows a Schild plot of these data with a $p \mathrm{~A}_{2}$ of 5.7 for ulimorelin.

Fig. 4 Ulimorelin is equally efficacious in saphenous arteries taken from wild type mice and mice lacking the ghrelin receptor. The histogram in panel A shows there is no difference in the magnitude of the inhibition of phenylephrine induced responses by $1-10 \mu \mathrm{M}$ ulimorelin in either genotype (2-way ANOVA). Panel B displays cumulative concentration contraction curves for ulimorelin, showing there is no difference in these responses between mice lacking the ghrelin receptor and wild-type mice. 
Table 1. The effect of ulimorelin, TZP102, capromorelin, ghrelin, desacyl ghrelin, and AZP-531 on phenylephrine-constricted rat saphenous arteries

\begin{tabular}{|l|l|l|}
\hline Drug (concentration) & $\begin{array}{l}\% \Delta \text { of phenylephrine } \\
\text { response (n) }\end{array}$ & $\begin{array}{l}\text { P value (compared to } \\
\text { ulimorelin } 30 \mu \mathrm{M})\end{array}$ \\
\hline $\begin{array}{l}\text { Ulimorelin } \\
(10 \mathrm{nM}-30 \mu \mathrm{M})\end{array}$ & $-66 \pm 5 \%(3-6)$ & NA \\
\hline $\begin{array}{l}\text { TZP102 } \\
(100 \mathrm{nM}-30 \mu \mathrm{M})\end{array}$ & $-2 \pm 4 \%(3-4)$ & $<0.001$ \\
\hline $\begin{array}{l}\text { Capromorelin } \\
(100 \mathrm{nM}-10 \mu \mathrm{M})\end{array}$ & $1 \pm 9 \%(3-4)$ & $<0.001$ \\
\hline $\begin{array}{l}\text { Ghrelin } \\
(1 \mathrm{nM}-1 \mu \mathrm{M})\end{array}$ & $0 \pm 3 \%(3-4)$ & $<0.001$ \\
\hline $\begin{array}{l}\text { Desacyl Ghrelin } \\
(1 \mathrm{nM}-1 \mu \mathrm{M})\end{array}$ & $-1 \pm 5 \%(3-4)$ & $<0.001$ \\
\hline $\begin{array}{l}\text { AZP-531 } \\
(1 \mathrm{nM}-1 \mu \mathrm{M})\end{array}$ & $-10 \pm 6 \%(3-4)$ & $<0.001$ \\
\hline
\end{tabular}

Data are expressed as \% phenylephrine contraction. For ulimorelin $\mathrm{E}_{\max } \pm$ standard error (best-fit parameters determined by nonlinear regression) is reported; for others mean \pm S.E.M. is reported. Data were analysed using 1-way ANOVA followed by Dunnett's post-tests. 
Table 2. Effects of ghrelin receptor antagonists, and other inhibitors and antagonists, on ulimorelininduced inhibition of phenylephrine contractions in rat saphenous arteries

\begin{tabular}{|c|c|c|c|c|}
\hline $\begin{array}{l}\text { Antagonist pre-incubation } \\
\text { (concentration) }\end{array}$ & $\begin{array}{l}\% \Delta \text { of phenylephrine } \\
\text { response by ulimorelin } \\
10 \mu M(n)\end{array}$ & $P$ value & $\begin{array}{l}\% \Delta \text { of phenylephrine } \\
\text { response by ulimorelin } \\
1 \mu M(n)\end{array}$ & $P$ value \\
\hline None & $-63 \pm 5(5)$ & NA & $-40 \pm 6(6)$ & NA \\
\hline YIL $781(3 \mu \mathrm{M})$ & $-48 \pm 8(4)$ & $P>0.05$ & $-32 \pm 9(4)$ & $P>0.05$ \\
\hline Nifedipine $(1 \mu \mathrm{M})$ & $-58 \pm 2(4)$ & $P>0.05$ & $-44 \pm 6(4)$ & $P>0.05$ \\
\hline Glibenclamide $(10 \mu \mathrm{M})$ & $-66 \pm 6(4)$ & $P>0.05$ & $-31 \pm 12(4)$ & $P>0.05$ \\
\hline L-NAME $(100 \mu \mathrm{M})$ & $-43 \pm 3(4)$ & $P>0.05$ & $-22 \pm 11(4)$ & $P>0.05$ \\
\hline Atropine $(1 \mu \mathrm{M})$ & $-30 \pm 4(4)$ & $P<0.01$ & $-42 \pm 13(4)$ & $P>0.05$ \\
\hline Propranolol $(1 \mu \mathrm{M})$ & $-44 \pm 12(4)$ & $P>0.05$ & $-28 \pm 13(4)$ & $P>0.05$ \\
\hline
\end{tabular}

Data were compared to the inhibition of phenylephrine-induced contractions by ulimorelin using 1-way ANOVA with Dunnett's post-tests. Note only pre-incubation of atropine $1 \mu \mathrm{M}$ caused a significant change in the magnitude of ulimorelin-induced inhibition of phenylephrine contractions. 
Table 3. The \% change in saphenous artery tension induced by ghrelin receptor agonists on contractions induced by phenylephrine, methoxamine, $60 \mathrm{mM}\left[\mathrm{K}^{+}\right]$, U46619 and ET-1.

\begin{tabular}{|l|l|l|l|l|}
\hline Stimulus & $\begin{array}{l}\% \Delta \text { ulimorelin } \\
10 \mu M(n)\end{array}$ & $\begin{array}{l}\% \Delta \text { ulimorelin } \\
1 \mu M(n)\end{array}$ & $\begin{array}{l}\% \Delta \text { ghrelin } \\
1 \mu M(n)\end{array}$ & $\begin{array}{l}\% \Delta \text { desacyl ghrelin } \\
1 \mu M(n)\end{array}$ \\
\hline Phenylephrine $(3 \mu \mathrm{M})$ & $-63 \pm 5(5)$ & $-41 \pm 6(6)$ & $-1 \pm 3(4)$ & $-2 \pm 5(4)$ \\
\hline Methoxamine $(3 \mu \mathrm{M})$ & $-42 \pm 4(3)$ & $-24 \pm 10(3)$ & NA & NA \\
\hline$\left[K^{+}\right](60 \mathrm{mM})$ & $6 \pm 3(4)^{\mathrm{b}}$ & $14 \pm 3(3)^{\mathrm{b}}$ & $\mathrm{NA}$ & $\mathrm{NA}$ \\
\hline U46619 $(100 \mathrm{nM})$ & $-1 \pm 6(3)^{\mathrm{a}}$ & $-2 \pm 1(3)^{\mathrm{a}}$ & $-12 \pm 15(3)$ & $0 \pm 9(3)$ \\
\hline ET-1 $(100 \mathrm{nM})$ & $47 \pm 40(4)^{\mathrm{c}}$ & $54 \pm 8(3)^{\mathrm{c}}$ & $30 \pm 6(3)^{\mathrm{a}}$ & $32 \pm 10(3)^{\mathrm{a}}$ \\
\hline
\end{tabular}

Data compared to the inhibition of phenylephrine-induced contractions using 1-way ANOVA with Dunnett's post-test. $\mathrm{a}=P<0.05 ; \mathrm{b}=P<0.01 ; \mathrm{c}=P<0.001$. 
Table 4. The contractile effects of ulimorelin, TZP102, capromorelin, ghrelin, desacyl ghrelin, and AZP-531 on rat saphenous arteries

\begin{tabular}{|l|l|l|}
\hline Drug (concentration) & $\begin{array}{l}\text { Drug-induced contraction as } \\
\% \Delta \text { of phenylephrine } \\
\text { response }(\mathrm{n})\end{array}$ & $\begin{array}{l}\text { P value compared to } \\
\text { ulimorelin } 30 \mu \mathrm{M}\end{array}$ \\
\hline $\begin{array}{l}\text { Ulimorelin } \\
(10 \mathrm{nM}-100 \mu \mathrm{M})\end{array}$ & $50 \pm 7(4)$ & NA \\
\hline $\begin{array}{l}\text { TZP102 } \\
(100 \mathrm{nM}-100 \mu \mathrm{M})\end{array}$ & $68 \pm 5(4)$ & $<0.01$ \\
\hline $\begin{array}{l}\text { Capromorelin } \\
(100 \mathrm{nM}-100 \mu \mathrm{M})\end{array}$ & $0 \pm 1(3)$ & $<0.001$ \\
\hline $\begin{array}{l}\text { Ghrelin } \\
(1 \mathrm{nM}-1 \mu \mathrm{M})\end{array}$ & $-2 \pm 0(3)$ & $<0.001$ \\
\hline $\begin{array}{l}\text { Desacyl Ghrelin } \\
(1 \mathrm{nM}-1 \mu \mathrm{M})\end{array}$ & $-2 \pm 0(3)$ & $<0.001$ \\
\hline $\begin{array}{l}\mathrm{AZP}-531 \\
(1 \mathrm{nM}-1 \mu \mathrm{M})\end{array}$ & $-2 \pm 1(3)$ & $<0.001$ \\
\hline
\end{tabular}

Data are expressed as \% phenylephrine contraction. For ulimorelin and TZP102 $\mathrm{E}_{\max } \pm$ standard error is reported; for others mean \pm S.E.M. is reported. Data were analysed using 1-way ANOVA followed by Dunnett's post-tests. 
Figure 1

A

$3 \mu \mathrm{M}$ phenylephrine

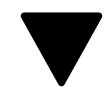

$1 \mu \mathrm{M}$ ulimorelin

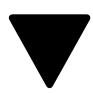

$1 \mu \mathrm{M}$ carbachol

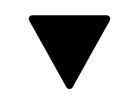

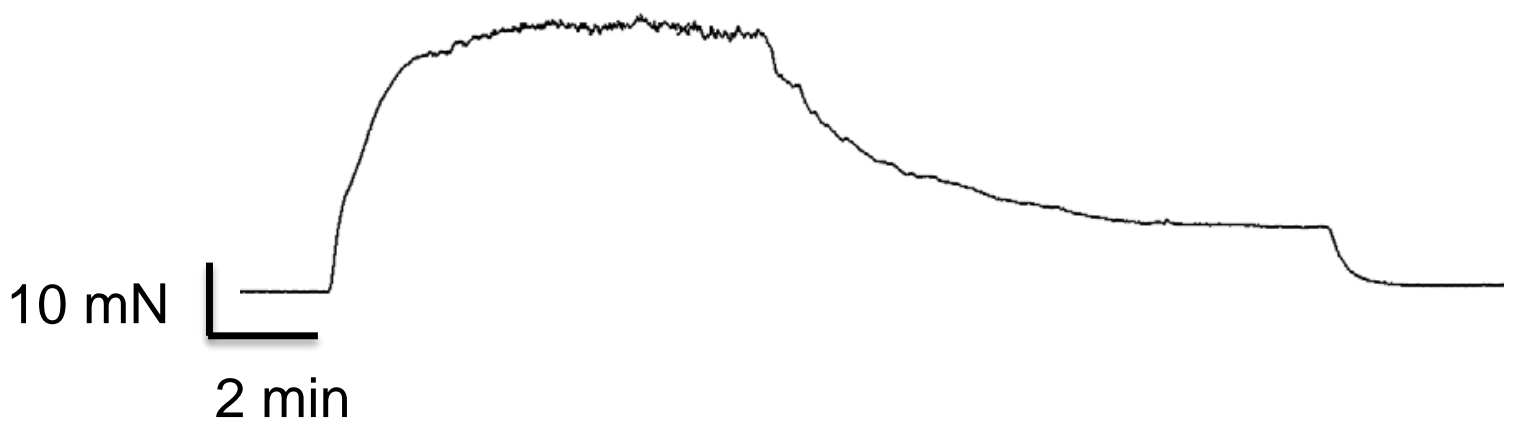

B

$10 \mu \mathrm{M}$ phenylephrine $\quad 10 \mu \mathrm{M}$ ulimorelin

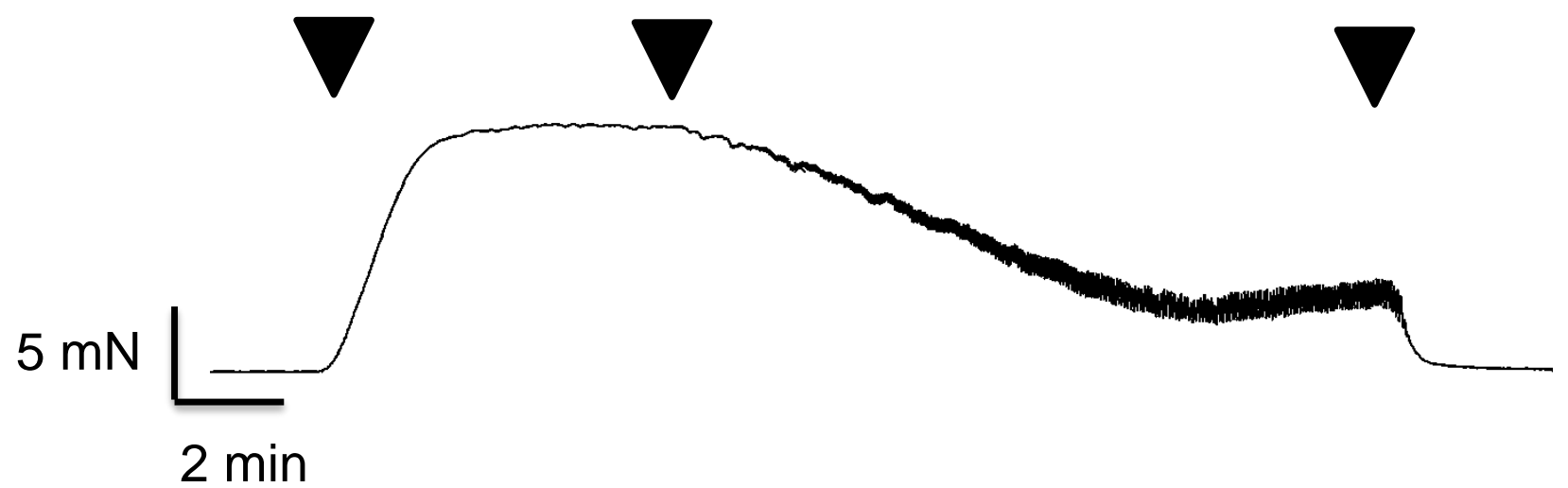

$1 \mu \mathrm{M}$ carbachol 


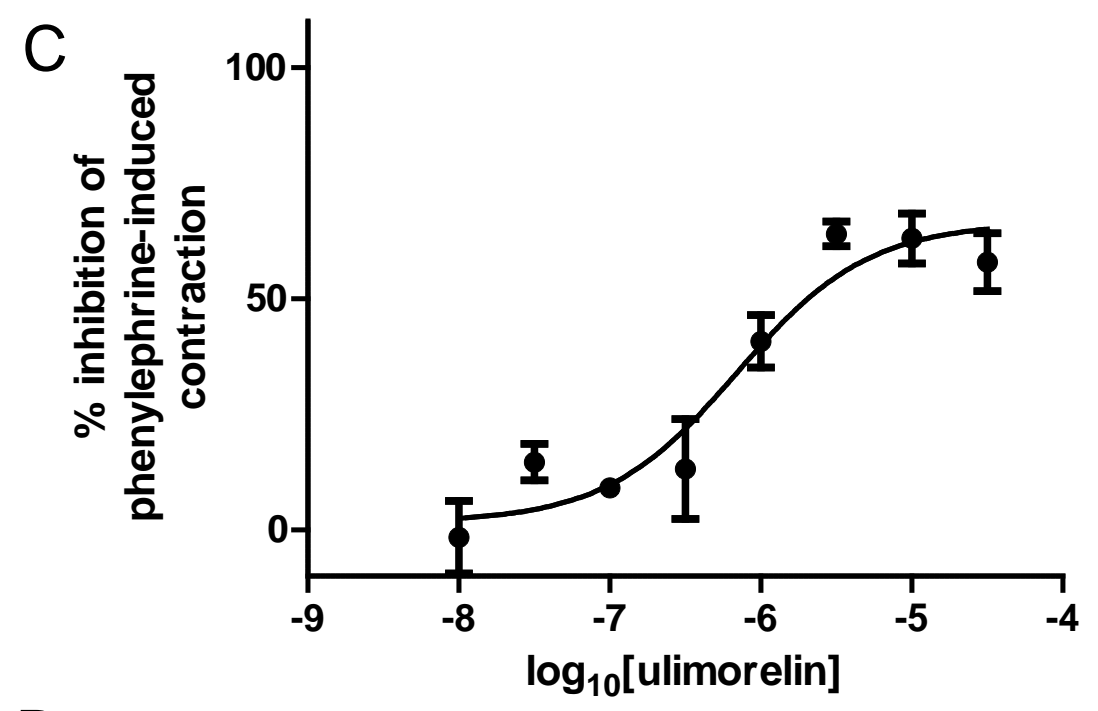

D

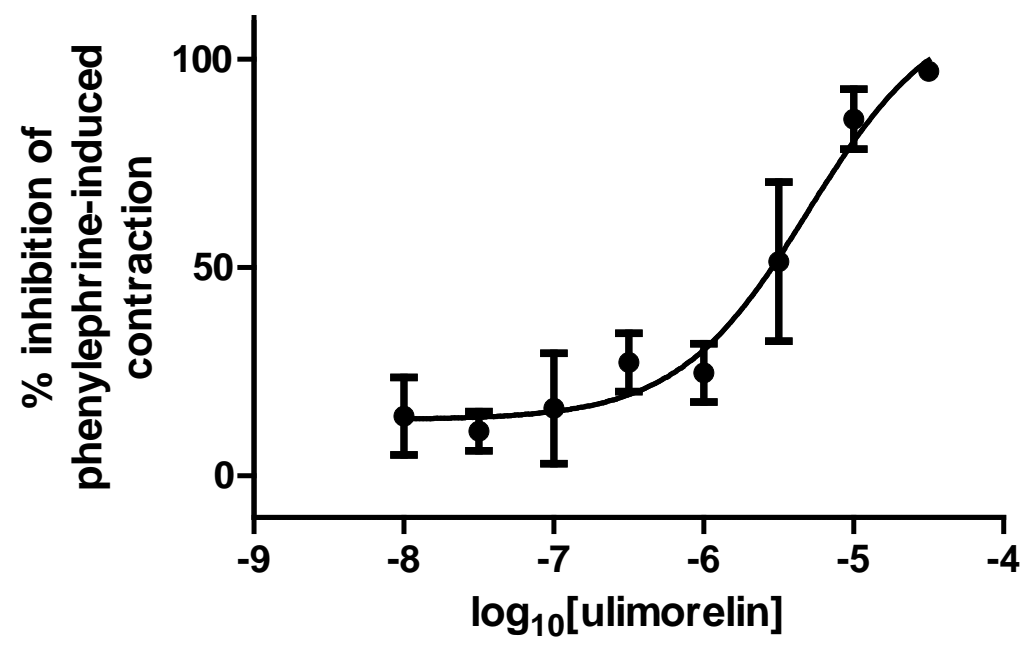


Figure 2

A

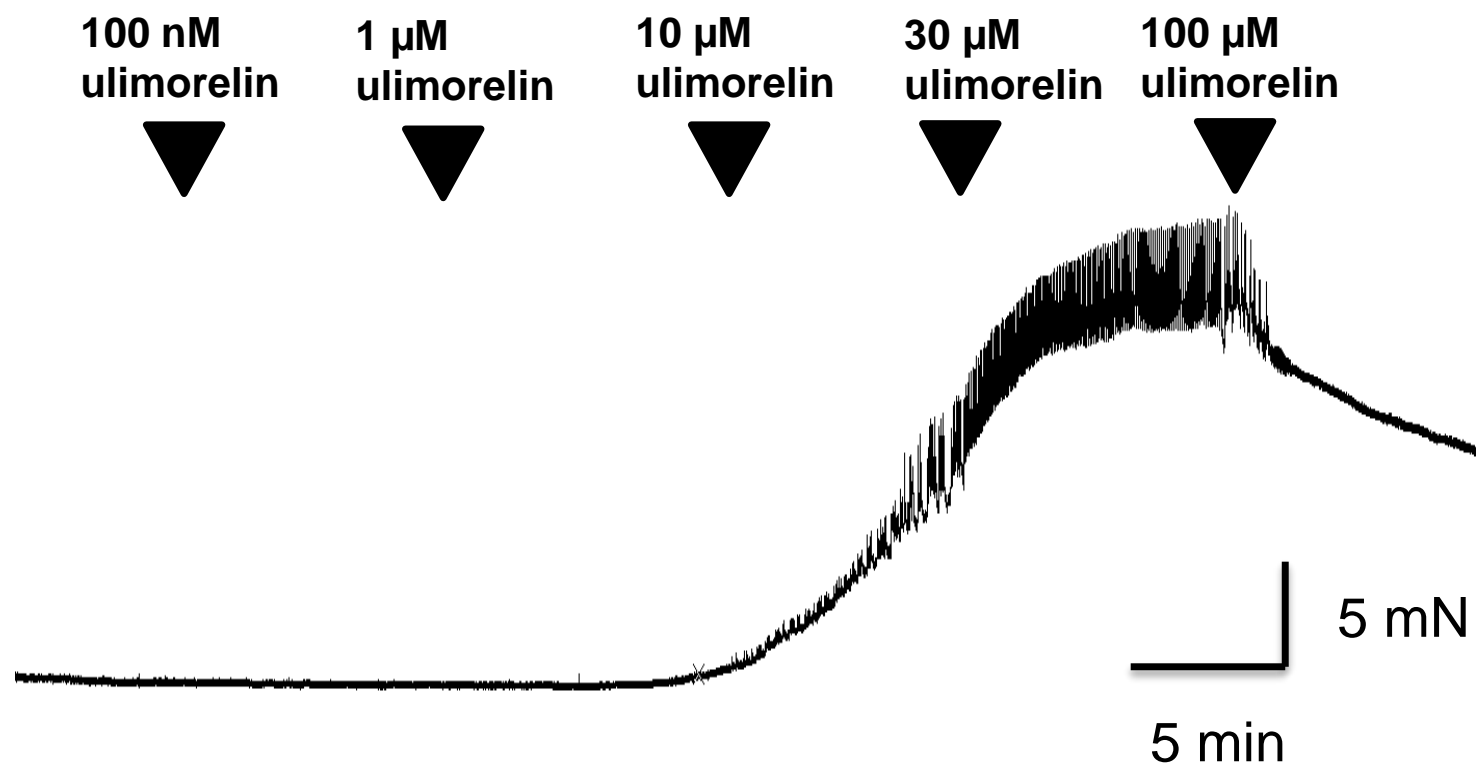

B

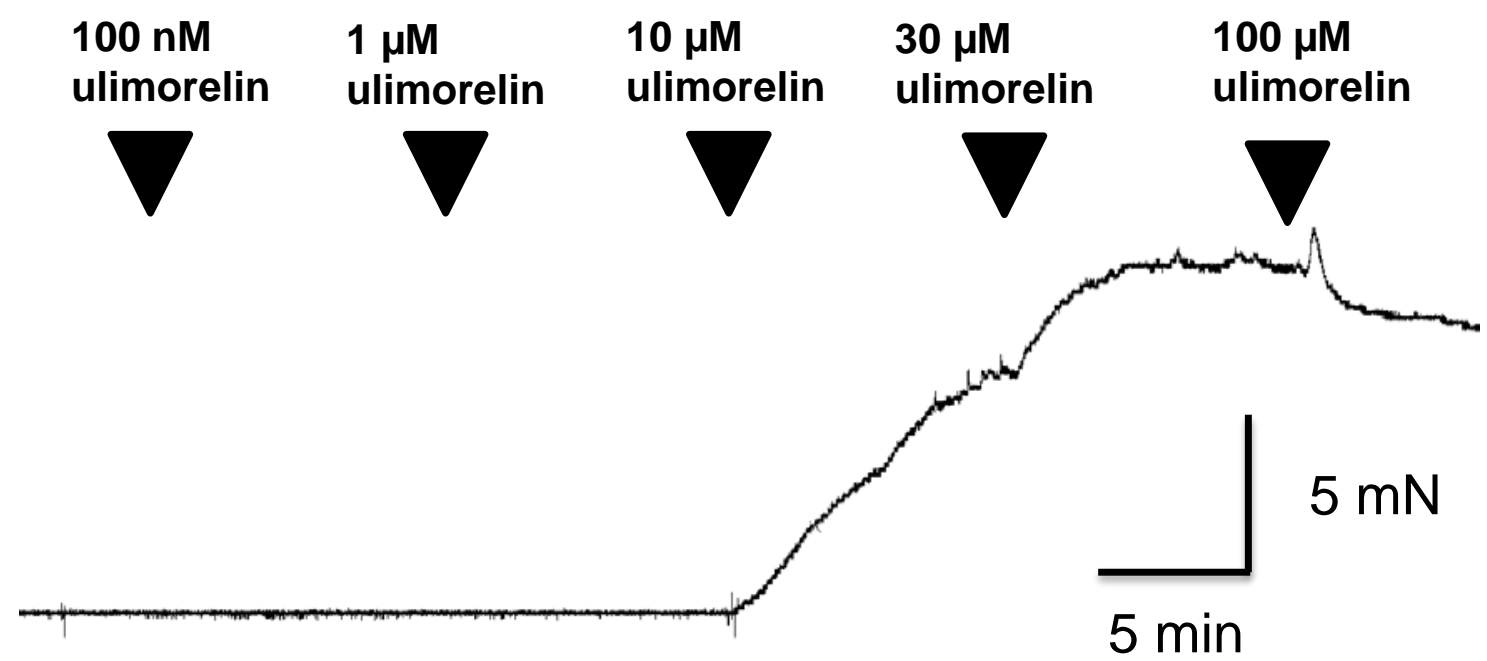


C

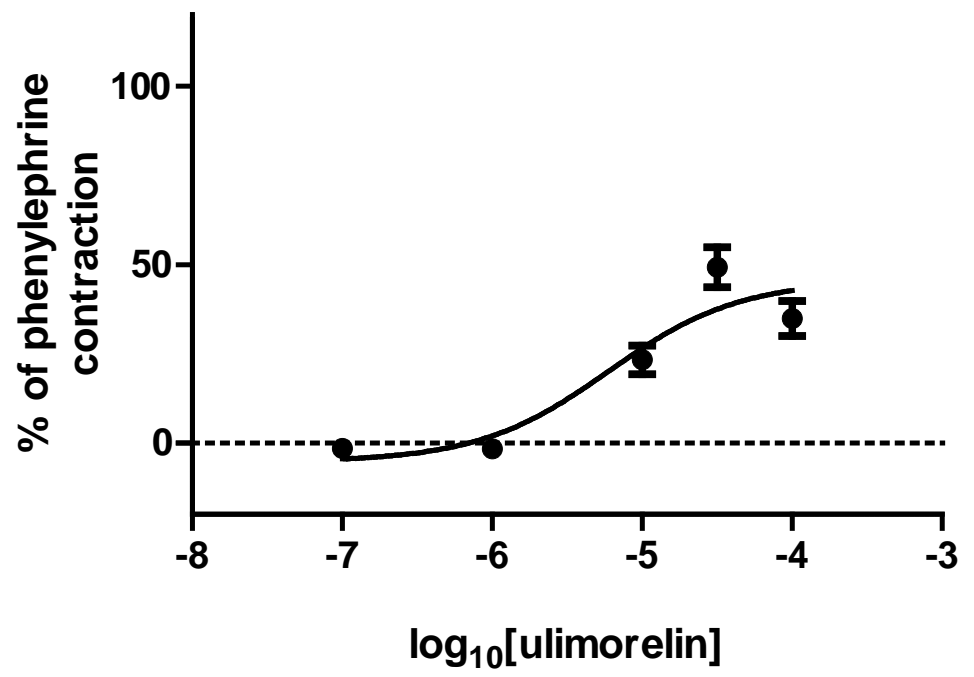

D

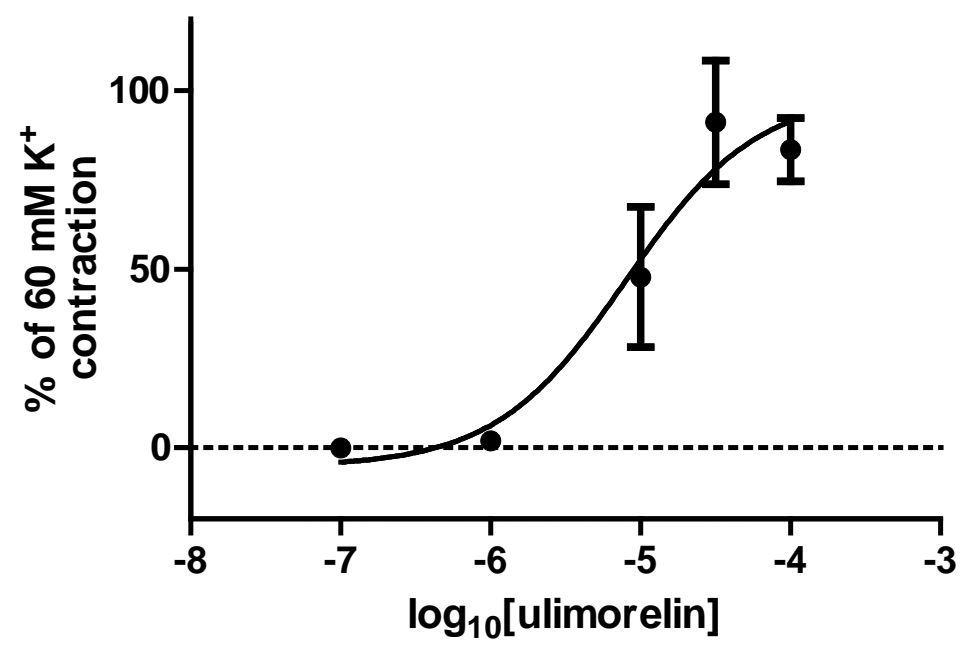


Figure 3

A

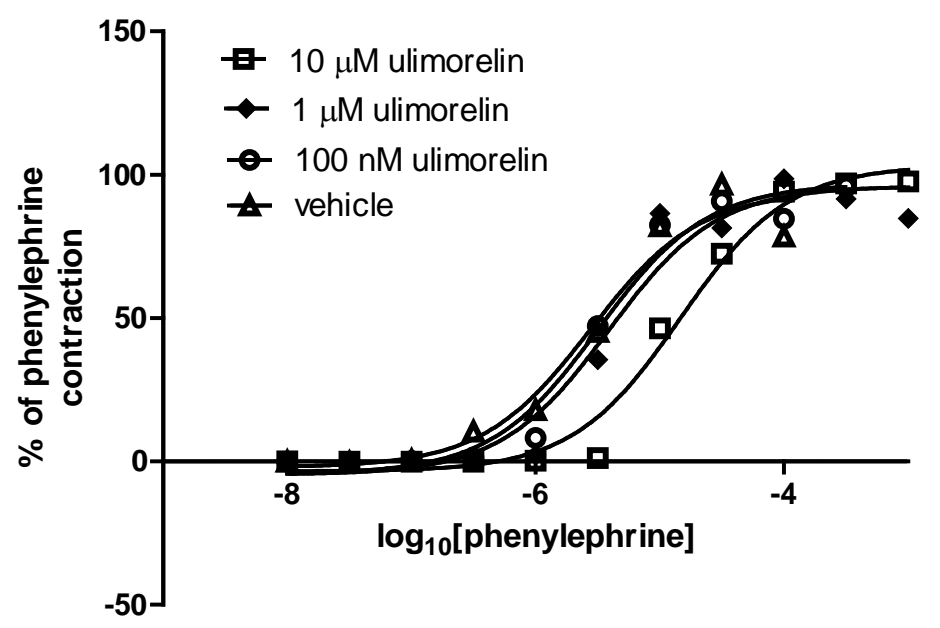

Schild analysis

B

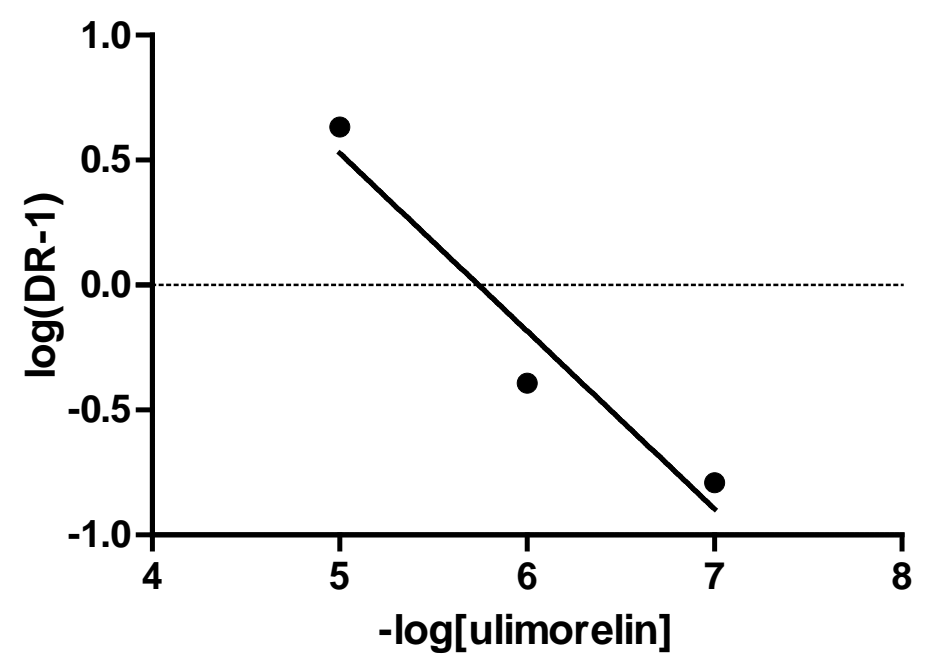


Figure 4

A

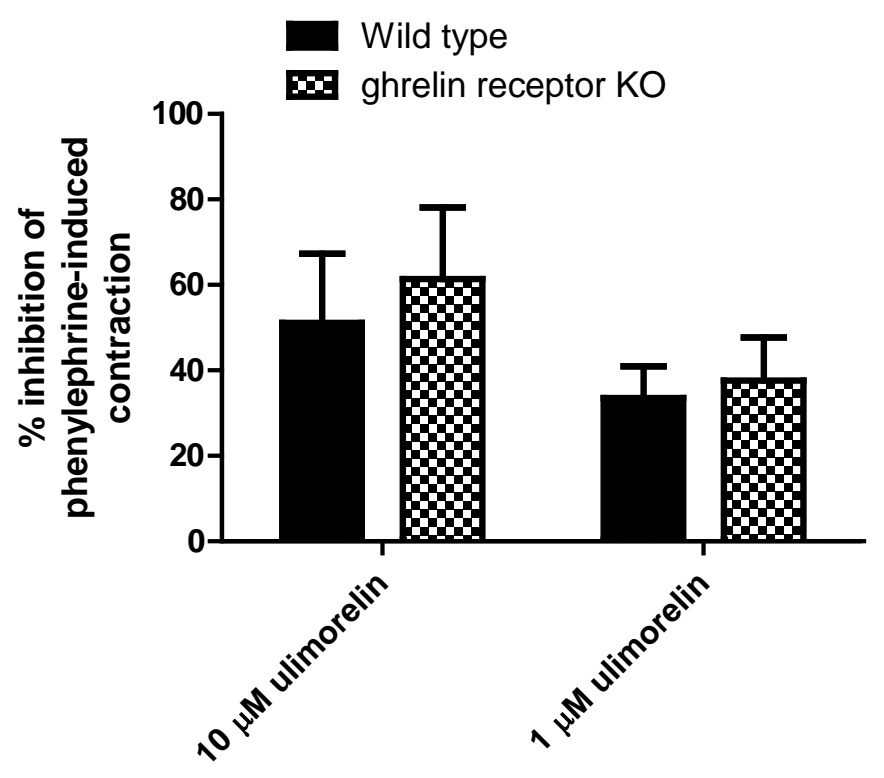

B

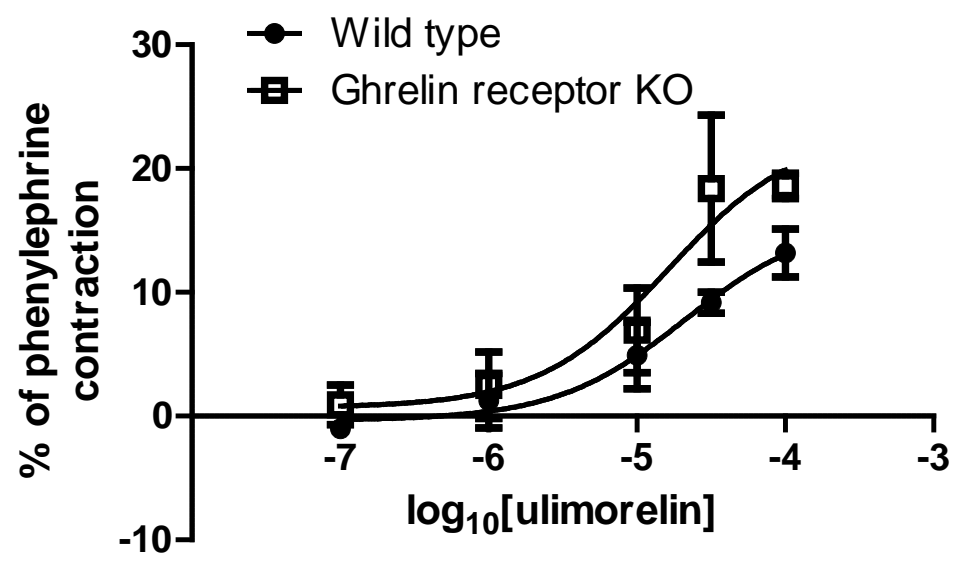




\section{University Library}

\section{- M M N E R VA A gateway to Melbourne's research publications}

Minerva Access is the Institutional Repository of The University of Melbourne

Author/s:

Broad, J;Callaghan, B;Sanger, GJ;Brock, JA;Furness, JB

Title:

Analysis of the ghrelin receptor-independent vascular actions of ulimorelin

Date:

2015-04-05

Citation:

Broad, J., Callaghan, B., Sanger, G. J., Brock, J. A. \& Furness, J. B. (2015). Analysis of the ghrelin receptor-independent vascular actions of ulimorelin. EUROPEAN JOURNAL OF PHARMACOLOGY, 752, pp.34-39. https://doi.org/10.1016/j.ejphar.2015.02.005.

Persistent Link:

http://hdl.handle.net/11343/52652 